\title{
Niche differentiation of two congeneric Phlomis species in Egypt
}

\author{
Abdel-Hamid A. Khedr ${ }^{*}$, Taha M. El-Katony ${ }^{1}$, Khalil M. Saad-Allah ${ }^{3}$, Fatma A. Ahmed ${ }^{2}$ and Mohamed I. \\ Kashlana $^{2}$ \\ ${ }^{1}$ Department of Botany and Microbiology, Faculty of Science, Damietta University, New Damietta City, Egypt. \\ ${ }^{2}$ Medicinal and Aromatic Plant Department, Ecology and Dry Land Agriculture Division, Desert Research Center, \\ Mataria, Cairo, Egypt. \\ ${ }^{3}$ Botany Department, Faculty of Science, Tanta University, Tanta, Egypt.
}

Received: 21 September 2020 /Accepted: 8 December 2020

*Corresponding author's E-mail: m_kashlana123@yahoo.com

\begin{abstract}
Phlomis aurea Decne. and Phlomis floccosa D. Don. exhibit different ecological and geographical distribution range in Egypt. Phlomis aurea is endemic to Saint Katherine Protectorate (SKP), South Sinai with narrow geographic distribution, but wide ecological range. Phlomis floccosa has wide geographical and ecological range within the coastal western Mediterranean coast of Egypt. Unlike $P$. floccosa, $P$. aurea has wide altitudinal range which increases its resistance to climate changes. Here, we assessed the effect of microhabitats on growth parameters and plant vigor of $P$. aurea and $P$. floccosa. The maximum EC of the soil in the various microhabitats supporting $P$. floccosa $(950$ $\mu \mathrm{S} / \mathrm{cm})$ is substantially higher than that of $P$. aurea $(110 \mu \mathrm{S} / \mathrm{cm})$. Both Phlomis species had low number of associated species which may be related to habitat aridity. The results indicate that the microhabitats supporting both species are the best environments for future conservation of these species under the impact of climate change.
\end{abstract}

Keywords: Altitude, Endemic species, Microhabitats; Mountains, Southern Sinai.

\section{Introduction}

Nature has bestowed on people a very rich botanical wealth and a large number of plant species growing in different parts of the world. Medicinal plants have always been a basic resource for human health since the beginning of civilization, perhaps since the Stone Age (Ghalem and Mohamed, 2008; Varalakshmi et al., 2011). Medicinal plants have played an important role in the traditional and orthodox system of medicine in curing different types of diseases (Jadon and Dixit, 2014). The use of traditional medicine and medicinal plants in most developing countries, as a normative basis for the maintenance of good health, has been widely observed (UNESCO, 1996). Nearly $80 \%$ of the world's population relies on traditional medicine, mostly plant extracts, for primary health care (Alluri and Majumdar, 2014).

The flora of Egypt comprises about 2165 plant species in addition to many species that have been successfully introduced and naturalized in Egypt (Khedr et al., 2002; Bolous, 2009). These species are distributed in different localities that vary in type of soil and prevailing climatic and conditions. Sinai Peninsula contains nearly 900 species and 250-300 associations (Danin, 1986). As a floristic 
region, it is part of the Saharo-Arabian territory with Saharo-Arabian, Mediterranean and Sudanian elements (Danin, 1983, 1986). Also, the mountains of Southern Sinai have been recognized as one of the important centers of plant diversity for the Saharo-Sindian (IranoTuranian) region of the Middle East (IUCN, 1994). The southern part of Sinai (including Saint Catherine Protectorate, SKP) represents a great pool of endemism (Zohary, 1973; Shmida, 1984). The flora of the southern Sinai mountains comprises about 540 species which constitute more than half of the number of species recorded in Sinai Peninsula. Among 31 endemic species to Sinai Peninsula, 24 species are confined to SKP; which contains $50 \%$ of the endemic species of Egypt (El-Hadidi and Hosny 2000). Such species should take a priority in any conservation program (Shaltout et al., 2004). Local Bedouins use more than 170 species of plants to treat various medical disorders from cold, digestive problems and skin disorders arising from bites and stings (Bailey and Danin, 1981). The soil surface characteristics, altitudinal gradients, and landform types provide microhabitats dominated by characteristic vegetation in SKP (Moustafa, 1990). These microhabitats are gorges, slopes, terraces, basins, wadis, and caves.

The Western Mediterranean coast of Egypt extends between Abu Qir and Sallum with a total length of $550 \mathrm{~km}$. It is one of the richest phytogeographical regions in Egypt because of its relatively high rainfall. It contains 1033 species which represent about $50 \%$ of the total flora of Egypt (Fakhry, 1994). According to Ayyad (1973), there are six main landforms in the Western Mediterranean section, namely: coastal sand dunes, rocky ridges, inland plateau, wadis, saline depressions, and non- saline depressions.

The genus Phlomis (family Lamiaceae) comprises more than 100 perennial herbal species distributed in Africa, Asia and Europe (Albaladejo et al., 2005; Kyriakopoulou et al., 2001). In the flora of Turkey, the genus Phlomis is represented by 34 species (Huber-Morath, 1982). In China, 43 species have already been recorded, with particularl occurrence in Sichuan and Yunnan districts ( $\mathbf{L i}$ and Hedge, 1994). In the flora of Iran, Phlomis is represented by 17 species, among which ten species are endemic (Rechinger, 1982). In the Egyptian flora, the genus Phlomis is represented by two species; $P$. aurea and $P$. floccosa. The value of the genus Phlomis lies in the presence of many compounds of medicinal values e.g. glycosides, steroids, organic acids, flavonoid p-counaroyl glucosides and 8-hydroxyflavone, 7allosylglucosides, diterpenoid glycosyl esters used to treat coughs and antifebrile. The Phlomis ingredients phenylpropanoid and phenethyl alcohol glycosides containing caffeic acid are active against human and animal cancer cells; in addition to the allenic fatty acid called phlomic acid (Khalmatov et al.,1983; Tanak 1985; Katagiri et al., 1994; Saracoglu et al.,1995; Aitzetmuller et al., 1997).

The present work has been conducted to evaluate the environmental factors affecting the distribution and abundance of the two congeneric Phlomis species $P$. aurea and $P$. floccosa growing naturally in different phytogeographical regions in Egypt.

\section{Materials and Methods}

\section{Studied species}

\section{1- Phlomis aurea Decne.}

Phlomis aurea Decne is a wild golden-woolly perennial, endemic to limited areas in South Sinai (the high mountainous region) under the vernacular name "Awarwar" (Tackholm, 1974). It prefers dry temperate regions (Boulos, 2002) and has been recorded in Saint Katharine Protectorate in gorges, slopes, terraces, wadi beds, basins and caves (Moustafa and Kamel, 1995; Ayyad et al., 2000; Abd EL-Wahab 2006; Khedr, 2007).

Serag et al. (2018) supposed that $P$. aurea would be highly resistant to drought; however, on the long run and with the expected harsher climate change scenarios there could be a severe decline in the plant population unless precautions have been followed. Several threats endanger $P$. aurea populations in the wild, including unmanaged human activities of severe overcutting and uprooting (for fuel) as well as the disturbances arising from incidence of the climate change-induced drought (Shaltout et al., 2004; Boulos, 2008).

\section{2- Phlomis floccosa D. Don.}

Phlomis floccosa D. Don is a white-woolly dwarf (up to $40 \mathrm{~cm}$ long) perennial herb, with 
large and thick undivided leaves of rounded cordate base and crenate margin. Bracts and calyx-teeth are terminated by hooked prickles and corolla is large, hairy and yellow (Tackholm, 1974).

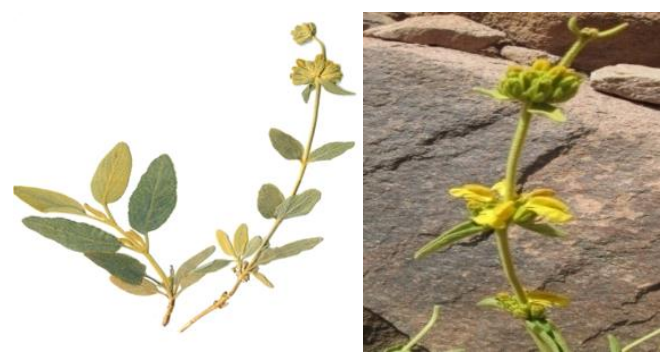

Fig. 1: Phlomis aurea herbarium sheet (Shabana, 2013).

The plant is common in the rocky habitats of the Western Mediterranean coast of Egypt and is locally known as "Zoheera". It prefers dry temperate regions (Boulos, 2002).
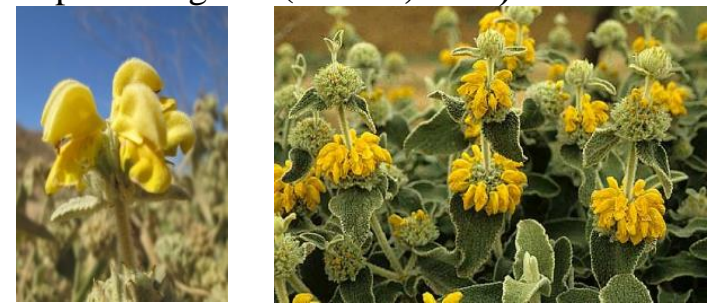

Fig. 2: Phlomis floccosa D. Don.

$P$. aurea and $P$. floccosa plants were collected from various microhabitats in Egypt (Wadi Bed, Slope, Gorge, Basin, Terraces, Plateau and Cleavage; $P$. aurea from SKP, South Sinai and $P$. floccosa from the western Mediterranean coast of Egypt.

\section{Study area}

\section{a) Sinai Peninsula}

The Saint Katherine Protectorate virtually extends over the entire mountain massif of southern Sinai across an area of $4350 \mathrm{~km}^{2}$. The protectorate was established in 1996 under the support of the Egyptian Environmental Affairs Agency (EEAA). It is located between $33^{\circ} 55^{\prime}$ to $34^{\circ} 30^{\prime}$ East, and $28^{\circ}$ $30^{\prime}$ to $28^{\circ} 35^{\prime}$ North with elevation range of 1300 to 2600 m ASL (Moustafa and Klopatek 1995).

The protectorate contains a wide range of habitats and landscapes, formed as a consequence of varying microclimatic conditions, altitudes and topography. The landscape ranges from rugged mountains, which includes the Mount Katherine (2642 m) to Egypt's highest peak whose slopes are incised by Wadi Rivers. The Wadi Rivers generally slope towards the east in the direction of the Gulf of Aqaba, or westwards towards the Gulf of Suez (El-Alqamy, 2002). The high mountainous region of southern Sinai can be considered as an "ecological island" surrounded by desert. The elevation and rock formations create variety of habitats, each with a characteristic water regime, microclimate and vegetation (Perevolotsky et al., 1989).

\section{b) The western Mediterranean section}

Ecologically, the western Mediterranean section (Mareotis coast) extends between Sallum and Abu Qir (550 km). The northwestern coastal region of Egypt covers an area of approximately 2.4 million ha, representing about $16.6 \%$ of the total national terrain and it is considered the richest part of the country with flora because of high precipitation and diverse habitats (Abd El Kader and Ahmed, 1981). This region may be subdivided into three distinct geomorphologic divisions (Gad et al., 1999): a northern coastal plain, an intermediate pediment plain and a southern tableland plateau.

\section{Selection of sites}

The present study was carried out in 20 main sites in South Sinai representing five microhabitats and 26 sites in the western Mediterranean region with four micro-habitats.

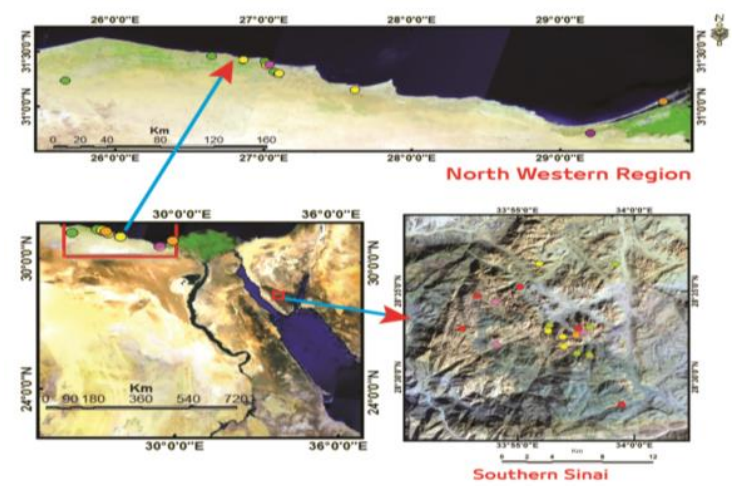

Fig. 3: Illustration map for the 20 and 26 sampled stand sites at different habitats in South Sinai and the western Mediterranean coast region.

\section{Soil Sampling and analysis}

Soil samples were taken at a depth of up to 20 $\mathrm{cm}$ in the rhizosphere region. The sampled soil was dried in the air, sieved through $2 \mathrm{~mm}$ mesh 
and stored for analysis. Particle size distribution was determined for air dried soil samples by mechanical analysis of the sieving method (Jackson, 1967).

Preparation of 1:5 soil suspension was done by shaking air-dried soil in distilled water for two hours Piper (1950). The supernatant was filtrated through filter paper and the clear extract was used for assay of soil reaction $(\mathrm{pH})$, soil salinity (EC), cations and anions by the procedures adopted by Allen et al. (1974). Soil $\mathrm{pH}$ was determined using Beckman bench type $\mathrm{pH}$ meter and soil electrical conductivity was measures by using EC meter Model 5995 according to (Page et al., 1982). Calcium, magnesium, chloride and bicarbonate were determined titrimetrically. Sulfates are calculated by subtracting the total soluble anions from the total soluble cations according to Richards, (1954), Wilde et al. (1978) and Allen et al. (1989). Calcium carbonate content of the dry soil was determined volumetrically using Collin's Calcimeter.

\section{Vegetation analysis}

Vegetation analysis was carried out using 46 plots of $10 \mathrm{~m} \times 10 \mathrm{~m}$ for both $P$. aurea and $P$. floccosa from the different microhabitats during 2015-2016. Relative coverage (\%) and relative frequency for each species in each plot were calculated and summed up to give its importance value (IV). These parameters were used to assess the general conditions of vegetation cover and to determine the community structure quantitatively (MuellerDombois and Ellenberg 1974, Shukla and Chandel 1989). Plant species were identified according to Täckholm (1974) and Boulos (2009).

\section{Statistical analysis}

Statistical analysis for the variation in data and their relationships were carried out by the aid of Excel, SPSS version 20.0 program and CANOCO program. The used statistical methods were according to the technique adopted by (Norusis, 2006 and 2007). Differences at $\mathrm{P} \leq 0.05,0.01$, and 0.001 were considered statistically significant, highly significant and very highly significant, respectively. In addition, we used DCA indirect ordination (Detrended Correspondence Analysis) which uses weighted averaging techniques for proper performance when the species have a uni-modal response to the environmental gradients. Canonical Correspondence Analysis (CCA), as a weighted averaging direct ordination whose axes are constrained by environmental variables, was applied to the same sets of vegetation and soil data. All methods have their merits in helping to understand the vegetation and environmental phenomena. The program CANOCO for Windows (Ter-Braak and Smilauer, 1998) was used for all ordinations.

\section{Results}

Geomorphological processes and physiographic factors

Soil characteristics differed according to geomorphological processes and physiographic factors in the different areas. Phlomis aurea spreads in microhabitats unique to SKP such as Wadi bed, Slope, Gorge, Basin, and Terraces, while $P$. floccosa expands along the North West coastal area of Egypt in some microhabitats such as Wadi bed, Slope, Cleavage and Plateau. $P$. aurea grows naturally in microhabitats of coarse soil fractions, which increase gradually from Terraces and Wadi bed through Slope and Gorge to reach the highest value in Basin. The coarse soil fractions fluctuated between $73.7 \%$ in Slope to $80.7 \%$ in Cleavage (Table1).

The soil $\mathrm{pH}$ of $P$. aurea was generally alkaline and ranged from 8.3 in Terraces to 8.8 in Slope. The $\mathrm{pH}$ of soil supporting $P$. floccosa was in the overall neutral, with an average $\mathrm{pH}$ of 7.35 for all sites (Table1).

EC in the soil samples of $P$. aurea varied significantly according to the change in soil structure in the different microhabitats, as it depends on the movement of ions in the soil. EC values were remarkably increased from Gorge $100.6 \mu \mathrm{S} / \mathrm{cm}$ to $165 \mu \mathrm{S} / \mathrm{cm}$ in Terraces. EC values of $P$. floccosa habitats was found to increase from Wadi bed $(520 \mu \mathrm{S} / \mathrm{cm})$ to its maximum value $(950 \mu \mathrm{S} / \mathrm{cm})$ in Plateau.

$\mathrm{CaCO}_{3}$ content varied from Terraces $6.0 \%$ to $11.5 \%$ at Slope habitat of $P$. aurea, where $P$. floccosa an increase from $14.3 \%, 31.9 \%$ in Plateau habitat (Table1).

The electric conductivity of soil in the various microhabitats at which $P$. floccosa can grow was found to increase gradually from Wadi bed habitat $(520 \mu \mathrm{S} / \mathrm{cm})$ to its maximum value $(950$ 
$\mu \mathrm{S} / \mathrm{cm}$ ) in Plateau habitat (Table1). The EC values in Slope, Cleavage, and Plateau habitats were higher by $24.13,34.62$ and $82.69 \%$, respectively compared to the EC value of Wadi bed habitat.

Table (1): Mean values ( \pm standard deviation) of some soil variables in the microhabitats of $P$. aurea and $P$. floccosa in Egypt.

\begin{tabular}{|c|c|c|c|c|c|c|c|c|c|}
\hline \multirow{2}{*}{$\begin{array}{l}\text { Soil } \\
\text { parameters }\end{array}$} & \multicolumn{5}{|c|}{ Microhabitats of Phlomis aurea } & \multicolumn{4}{|c|}{ Microhabitats of Phlomis floccosa } \\
\hline & Wadi bed & Slope & Gorge & Basin & Terraces & Wadi bed & Slope & Cleavage & Plateau \\
\hline Coarse fractions $(\%)$ & $81.4 \pm 8.7$ & $79.9 \pm 14.3$ & $83.2 \pm 9.2$ & $83.5 \pm 7$ & 81.0 & $79.5 \pm 12.1$ & $73.7 \pm 9.6$ & $80.7 \pm 4.4$ & $76 \pm 15.3$ \\
\hline Fine fractions $(\%)$ & $18.6 \pm 8.7$ & $20.1 \pm 14.3$ & $16.8 \pm 9.2$ & $16.5 \pm 7$ & 19.0 & $20.5 \pm 12.1$ & $26.3 \pm 9.6$ & $19.3 \pm 4.4$ & $24 \pm 15.3$ \\
\hline $\mathrm{pH}$ & $8.9 \pm 0.2$ & $8.8 \pm 0.2$ & $8.9 \pm 0.2$ & $8.9 \pm 0.1$ & 8.3 & $7.3 \pm 0.2$ & $7.4 \pm 0.1$ & $7.3 \pm 0.2$ & $7.4 \pm 0.2$ \\
\hline $\mathrm{EC}\left(\mu \mathrm{S} \mathrm{cm}^{-1}\right)$ & $113.6 \pm 74$ & $117.2 \pm 40$ & $100.6 \pm 62$ & $110.5 \pm 13.2$ & 165.0 & $520 \pm 154$ & $645.45 \pm 206$ & $700 \pm 264$ & $950 \pm 777$ \\
\hline $\operatorname{TDS}\left(\mu \mathrm{g} \mathrm{g}^{-1} \mathrm{DW}\right)$ & $48.6 \pm 37$ & $54.0 \pm 26$ & $44 \pm 23$ & $49.0 \pm 5.4$ & 106.0 & $343.2 \pm 102$ & $426 \pm 136$ & $462 \pm 174$ & $627 \pm 213$ \\
\hline $\mathrm{CaCO}_{3}(\% \mathrm{DW})$ & $9.0 \pm 4.3$ & $11.5 \pm 4.9$ & $11.0 \pm 8.6$ & $8.1 \pm 3.1$ & 6.0 & $14.3 \pm 5.5$ & $15.5 \pm 6.4$ & $16.6 \pm 3.7$ & $31.9 \pm 20.7$ \\
\hline $\mathrm{Ca}^{2+}\left(\mathrm{mmol} \mathrm{L}^{-1}\right)$ & $2.1 \pm 1.2$ & $2.6 \pm 1.3$ & $2.8 \pm 2.4$ & $4.0 \pm 2$ & 5.0 & $1.6 \pm 0.8$ & $2.1 \pm 1$ & $2.3 \pm 1.2$ & $3.5 \pm 3.5$ \\
\hline $\mathrm{Mg}^{2+}\left(\mathrm{mmol} \mathrm{L}^{-1}\right)$ & $4.7 \pm 0.6$ & $5.3 \pm 1.6$ & $6.5 \pm 3.7$ & $4.1 \pm 0.8$ & 13.5 & $0.7 \pm 0.4$ & $1.0 \pm 0.5$ & $1.1 \pm 0.6$ & $2.2 \pm 2.5$ \\
\hline $\mathrm{HCO}_{3}^{-}\left(\mathrm{mmol} \mathrm{L}^{-1}\right)$ & $5.4 \pm 1.9$ & $4.9 \pm 1.6$ & $6.2 \pm 1.8$ & $3.9 \pm 1.9$ & 3.5 & $1.2 \pm 0.5$ & $1.6 \pm 0.6$ & $1.0 \pm 0$ & $1.0 \pm 0.0$ \\
\hline $\mathrm{Cl}^{-}\left(\mathrm{mmol} \mathrm{L}^{-1}\right)$ & $2.8 \pm 0.7$ & $2.8 \pm 1$ & $2.6 \pm 0.4$ & $2.8 \pm 0.7$ & 4.3 & $3.0 \pm 1.5$ & $3.5 \pm 1.8$ & $3.3 \pm 1$ & $5.8 \pm 5.3$ \\
\hline $\mathrm{SO}_{4}{ }^{2-}\left(\mathrm{mmol} \mathrm{L}^{-1}\right)$ & $7.0 \pm 4.7$ & $5.9 \pm 3.6$ & $7.6 \pm 5.6$ & $6.3 \pm 2.4$ & 27.5 & $1.1 \pm 0.8$ & $1.4 \pm 1$ & $2.8 \pm 2.9$ & $2.8 \pm 2.5$ \\
\hline
\end{tabular}

\section{Modeling species response curves}

The model in Fig. 4 is used to describe the relationship between a quantity of a particular species ( $P$. aurea and $P$. floccosa) and the environmental gradients of community variation. The desert micro-habitats at the study area leads to a little variation. The importance value index of $P$. aurea was negatively correlated with the fine fractions, $\mathrm{EC}, \mathrm{CaCO}_{3}$ and $\mathrm{Cl}^{-}$and positively correlated with sand, $\mathrm{pH}$, $\mathrm{Ca}^{2+}, \mathrm{Mg}^{2+}, \mathrm{HCO}_{3}$, and $\mathrm{SO}_{4}{ }^{2-}$.

On the other hand, the importance value index of $P$. floccosa was negatively correlated with the sand, $\mathrm{pH}, \mathrm{Ca}^{2+}, \mathrm{Mg}^{2+}, \mathrm{HCO}_{3}, \mathrm{Cl}^{-}$and $\mathrm{SO}_{4}{ }^{2-}$. However, the importance value index of $P$. floccosa was positively correlated with the fine fractions, $\mathrm{EC}$ and $\mathrm{CaCO}_{3}$.

\section{Species abundance in the different microhabitats}

The data in Table (2) is concerned with the vegetation analysis of the species associated with $P$. aurea and $P$. floccosa in Egypt 25 associated species were recorded throughout the present study, with higher importance value (IV) in the different microhabitats where Phlomis species are common.

$P$. aurea is distributed in different landforms of microhabitats at SKP with high importance index represented in Terraces, Gorge, Basin, Slope, and Wadi bed (74.71, 72.68, 62.68, 49.65 and 42.41 , respectively).

In the present survey, the Wadi bed and the Gorge were relatively floristically rich. We recorded 13 species belonging to Phanerophytes and Chamaephytes in those two microhabitats. Meanwhile, the Slope and Basin microhabitats were moderate floristically, with 11 plant species. Although Terraces microhabitat possessed the largest importance value for $P$. aurea, it has poor vegetation ( 5 species only).

According to vegetation analysis, the data represented in Table (2) illustrated that the Wadi bed has 12 plant species associated in their distribution with $P$. aurea. The maximum IVs were 37.62 and 30.09 for Achillea fragrantissima and Capparis spinosa, respectively. The minimum IV was 10.56 for Euphorbia boviana. The IV of $P$. aurea was four-fold higher than that of Euphorbia boviana.

The vegetation in Slope habitats reflected 10 species associated with $P$. aurea, which has $49.65 \mathrm{IV}$. The highest IVs for the associated species were for Globularia arabica, Teucrium polium and Stachys aegyptiaca $(32.05,27.57$ and 20.57, respectively). While the least IV was 9.59 for Silene schimperiana.

The Gorge habitat was represented by 12 species growing with $P$. aurea, which is dominated by 72.68 . The largest IV behind $P$. aurea was recorded for Tanacetum sinaicum (23.46) and the least value was recorded for Thymus decussates (9.41).

Basin habitat was characterized by moderate vegetation, as it recorded 10 plant species associated in their distribution with $P$. aurea. The IVs in Basin habitat varied from a maximum (62.47) for $P$. aurea and a minimum (9.85) for Globularia arabica. Origanum 
syriacum, an endemic species in Saint Katherine Protectorate, occupied the second position (40.48) in the Basin microhabitat.
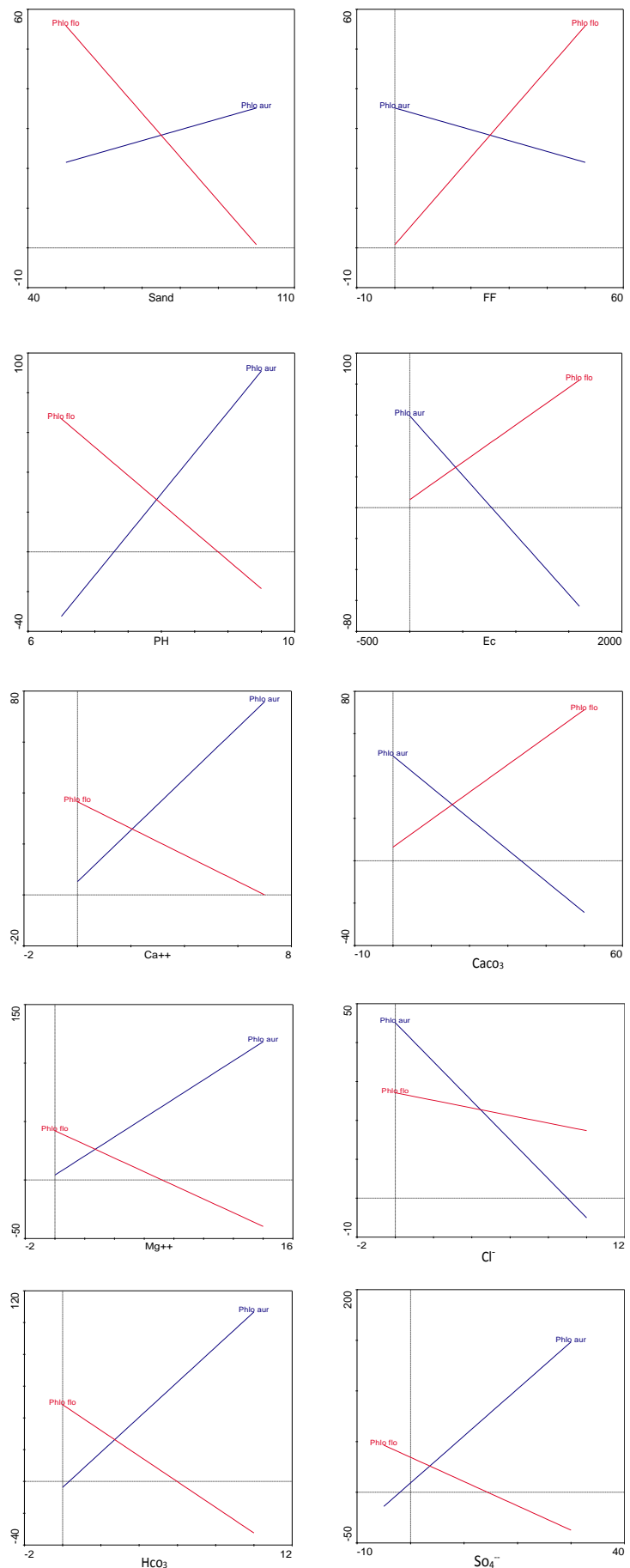

Fig. 4: Modeling of response curves for $P$. aurea and $P$. floccosa growing in Egypt to edaphic factors.

The vegetation in the Terraces habitat pointed out that there are four species associated with the dominate species $P$. aurea (74.71) in their distribution. The least IV was represented by 22.68 for Stachys aegyptiaca.
Phlomis floccosa is native to North Africa and distributed in the North West region of Egypt in various microhabitats along the coast. The microhabitats inhibited by the target plant are represented in Wadi bed, Slope, Cleavage and Plateau with IVs of $41.43,43.15,55.99$ and 43.92 respectively. Thus, $P$. floccosa is widely distributed in Cleavage microhabitat than the other localities.

Data in Table (2) illustrate the vegetation analysis in the various microhabitats at which $P$. floccosa is widely distributed. Firstly, the Wadi bed habitat has 11 plant species associated with $P$. floccose. The highest IV after the common plant was 39.68 for Amaranthus viridis, and the least value (10.62) was for Asphodelus ramosus. Ferula marmarica was characteristic of Wadi bed habitat than other habitats.

Secondary, Euphorbia dendroides was prevalent in the Slope habitat with IV slightly (1.04 times) higher than that of $P$. floccosa. The vegetation in Slope habitat recorded IVs of 45.09, 43.15 and 37.76 for Euphorbia dendroides, $P$. floccosa and Thymus capitatus, respectively. The least IV (10.89) was represented by Lycium shawii. As an important note, $P$. floccosa was four-folds higher than Lycium shawii, and Thymus capitatus appeared only in this habitat away from other habitats.

Thirdly, Cleavage habitat was the richest with the flora, as there were 13 plant species recorded in this habitat. By the IV index, the maximum value (55.99) was observed for $P$. floccosa and the lowest value (10.06) was for Rumex pictus. Owing to the data represented in Table (2), Leontodon hispidulus was distinctive in this habitat but with IV of about $1 / 3$ that of $P$. floccosa.

Finally, the lowest floral record was in Plateau habitat, with about 8 plant species associated with the P. floccosa. Artemisia herba-alba was the most common in this habitat with IV $25.43 \%$ greater than that of P. floccosa. The least IV (10.21) was noticed for Periploca angustifolia. Interestingly, P. floccosa was 4.3 times more common than Periploca angustifolia.

an intermediate gradient of $\mathrm{So}_{4}{ }^{2-}, \mathrm{CaCo}_{3}$ and $\mathrm{Ca}^{2+}$. Similar comparisons make it clear that the $P$. floccosa occupying the medium position between fine fractions and $\mathrm{So}_{4}{ }^{2-}$. However, some of the most soil variables affect of the variation plant species such as sand, $\mathrm{Cl}^{-}, \mathrm{Mg}^{+2}$, $\mathrm{CaCO}_{3}$, fine fractions and $\mathrm{SO}_{4}{ }^{2-}$. 
Table (2): Importance value (IV) out of 200 for Phlomis aurea, P. floccosa and the associated species at the different microhabitats in Egypt.

\begin{tabular}{|c|c|c|c|c|c|c|c|c|c|c|}
\hline \multirow[b]{2}{*}{ Species } & \multicolumn{5}{|c|}{ Microhabitats of Phlomis aurea } & \multirow[b]{2}{*}{ Species } & \multicolumn{4}{|c|}{ Microhabitats of Phlomis floccosa } \\
\hline & $\begin{array}{c}\text { Wadi } \\
\text { bed } \\
(12) \\
\end{array}$ & $\begin{array}{l}\text { Slope } \\
(10)\end{array}$ & $\begin{array}{l}\text { Gorge } \\
\text { (12) }\end{array}$ & $\begin{array}{c}\text { Basin } \\
(10)\end{array}$ & $\begin{array}{c}\text { Terraces } \\
\text { (4) }\end{array}$ & & $\begin{array}{c}\text { Wadi } \\
\text { bed } \\
(11) \\
\end{array}$ & $\begin{array}{l}\text { Slope } \\
(10)\end{array}$ & $\begin{array}{c}\text { Cleavage } \\
\text { (13) }\end{array}$ & $\begin{array}{l}\text { Plateau } \\
\text { (8) }\end{array}$ \\
\hline Phlomis aurea Decne. & 42.41 & 49.65 & 72.68 & 62.47 & 74.71 & $\begin{array}{l}\text { Phlomis floccosa } \\
\text { D. Don }\end{array}$ & 41.43 & 43.15 & 55.99 & 43.92 \\
\hline $\begin{array}{l}\text { Achillea } \\
\text { fragrantissima } \\
\text { (Forssk.) Sch.Bip. }\end{array}$ & 37.62 & 19.35 & 12.95 & - & - & $\begin{array}{l}\text { Amaranthus } \\
\text { viridis } \mathrm{L} .\end{array}$ & 39.68 & 31.52 & - & - \\
\hline $\begin{array}{ll}\text { Alkanna } & \text { orientalis } \\
\text { (L.) Boiss. } & \end{array}$ & 15.66 & & 11.46 & - & 36.96 & $\begin{array}{l}\text { Artemisia herba- } \\
\text { alba Asso. }\end{array}$ & 11.24 & & 16.84 & 55.09 \\
\hline $\begin{array}{l}\text { Artemisia herba-alba } \\
\text { Asso. }\end{array}$ & 25.29 & 17.77 & 13.83 & 10.87 & - & $\begin{array}{l}\text { Asphodelus } \\
\text { ramosus } \mathrm{L} \text {. }\end{array}$ & 10.62 & 13.80 & - & 19.19 \\
\hline $\begin{array}{l}\text { Asclepias sinaica } \\
\text { (Boiss.) Muschl. }\end{array}$ & 15.38 & - & - & 9.80 & - & $\begin{array}{l}\text { Atriplex halimus } \\
\text { L. }\end{array}$ & 11.34 & - & - & - \\
\hline $\begin{array}{l}\text { Astragalus sieberi } \\
\text { DC. }\end{array}$ & - & 9.68 & - & - & - & $\begin{array}{l}\text { Carduncellus } \\
\text { eriocephalus } \\
\text { Boiss. } \\
\text { Boiss. } \\
\text { Boiss. } \\
\text { Boiss. } \\
\end{array}$ & 11.84 & - & - & - \\
\hline $\begin{array}{l}\text { Ballota undulata } \\
\text { (Fresen.) Benth. }\end{array}$ & - & 9.85 & - & - & - & $\begin{array}{l}\text { Convolvulus } \\
\text { lanatus Vahl. }\end{array}$ & - & - & 11.57 & - \\
\hline $\begin{array}{l}\text { Capparis spinosa } \\
\text { L.var. spinosa }\end{array}$ & 30.09 & - & 14.48 & - & - & $\begin{array}{l}\text { Chiliadenus } \\
\text { candicans } \\
\text { (Delile) Boiss. }\end{array}$ & 13.03 & 12.36 & 13.04 & - \\
\hline $\begin{array}{l}\text { Chiliadenus montanus } \\
\text { Vahl Brullo. }\end{array}$ & - & - & - & 11.18 & - & $\begin{array}{l}\text { Cynodon } \\
\text { dactylon L. Pers. }\end{array}$ & - & 11.38 & - & - \\
\hline $\begin{array}{l}\text { Cotoneaster } \\
\text { orbicularis Schltdl. }\end{array}$ & - & - & 10.84 & - & - & $\begin{array}{l}\text { Deverra tortuosa } \\
\text { (Desf.) DC. }\end{array}$ & 7.62 & 9.7 & 10.84 & - \\
\hline $\begin{array}{l}\text { Crataegus sinaica } \\
\text { Boiss. }\end{array}$ & 17.75 & - & - & 12.33 & - & $\begin{array}{l}\text { Emex spinosa } \mathrm{L} \text {. } \\
\text { Campd }\end{array}$ & - & - & 12.06 & - \\
\hline $\begin{array}{l}\text { Echinops } \\
\text { spinosissimus Turra. }\end{array}$ & & & 13.74 & - & - & $\begin{array}{l}\text { Euphorbia } \\
\text { dendroides } \mathrm{L} .\end{array}$ & - & 45.09 & - & - \\
\hline $\begin{array}{l}\text { Euphorbia boviana } \\
\text { Fayed. }\end{array}$ & 10.56 & - & - & - & - & $\begin{array}{l}\text { Fagonia cretica } \\
\text { L. }\end{array}$ & - & 13.03 & - & - \\
\hline $\begin{array}{l}\text { Fagonia mollis var. } \\
\text { hispida Zohary }\end{array}$ & - & - & - & - & 28.48 & $\begin{array}{l}\text { Ferula } \\
\text { marmarica Asch. } \\
\text { \& Taub. }\end{array}$ & 31.31 & - & - & - \\
\hline $\begin{array}{l}\text { Globularia arabica } \\
\text { Jaub. \& Spach. }\end{array}$ & 16.49 & 32.05 & - & 10.85 & - & $\begin{array}{l}\text { Gymnocarpos } \\
\text { decandrum } \\
\text { Forssk. }\end{array}$ & & 11.21 & 16.55 & 32.15 \\
\hline $\begin{array}{l}\text { Hyoscyamus boveanus } \\
\text { (Dunal) Asch. \& } \\
\text { Schweinf. }\end{array}$ & 26.58 & - & - & - & - & $\begin{array}{l}\text { Haloxylon } \\
\text { scoparium } \\
\text { Pomel. } \\
\end{array}$ & - & - & 18.31 & 18.51 \\
\hline $\begin{array}{l}\text { Hypericum sinaicum } \\
\text { Boiss. }\end{array}$ & 12.12 & - & - & - & - & $\begin{array}{l}\text { Leontodon } \\
\text { hispidulus } \\
\text { (Delile) Boiss. } \\
\end{array}$ & - & & 21.15 & - \\
\hline $\begin{array}{l}\text { Nepeta septemcrenata } \\
\text { Benth. }\end{array}$ & - & - & 9.75 & 19.87 & - & $\begin{array}{l}\text { Lycium shawii } \\
\text { Roem. \& Schult. }\end{array}$ & - & 10.89 & 27.67 & 25.04 \\
\hline $\begin{array}{l}\text { Origanum syriacum } \\
\text { Boiss. Greater \& \& } \\
\text { Burdet.var. sinaicum }\end{array}$ & - & 15.83 & 13.24 & 40.48 & - & $\begin{array}{l}\text { Lygeum spartum } \\
\text { Loefl. ex L. }\end{array}$ & 14.71 & - & - & 12.33 \\
\hline Peganum harmala L. & 11.36 & - & - & - & - & $\begin{array}{l}\text { Periploca } \\
\text { angustifolia } \\
\text { Labill. } \\
\end{array}$ & 15.32 & - & 16.84 & 10.21 \\
\hline $\begin{array}{l}\text { Silene schimperiana } \\
\text { Boiss. }\end{array}$ & - & 9.59 & - & - & - & $\begin{array}{l}\text { Rhamnus } \\
\text { lyciodes L. }\end{array}$ & - & - & 14.16 & - \\
\hline $\begin{array}{l}\text { Stachys aegyptiaca } \\
\text { Pers. }\end{array}$ & - & 20.57 & - & - & 22.68 & Rumex pictus L. & - & - & 10.06 & - \\
\hline $\begin{array}{l}\text { Tanacetum sinaicum } \\
\text { fresen. Delile ex } \\
\text { Bremer \& humphries. }\end{array}$ & - & 12.64 & 27.50 & 23.46 & - & $\begin{array}{l}\text { Salvia aegyptiaca } \\
\text { L. }\end{array}$ & - & - & 15.76 & - \\
\hline Teucrium polium $\mathrm{L}$. & 14.93 & 27.85 & 13.69 & 17.21 & 36.96 & $\begin{array}{l}\text { Stipa lagascae } \\
\text { Roem. \& Schult. }\end{array}$ & 12.96 & - & - & - \\
\hline $\begin{array}{l}\text { Thymus decussatus } \\
\text { Benth. }\end{array}$ & - & & 9.41 & - & - & $\begin{array}{l}\text { Thymelaea } \\
\text { hirsuta L. Endl. }\end{array}$ & 11.21 & 16.71 & - & 25.26 \\
\hline $\begin{array}{l}\text { Zilla spinosa (L.) } \\
\text { Prrantl in Engl. \& } \\
\text { Prantl. }\end{array}$ & - & - & 9.47 & 12.75 & - & $\begin{array}{l}\text { Thymus capitatus } \\
\text { L. Link }\end{array}$ & - & 37.76 & - & - \\
\hline
\end{tabular}



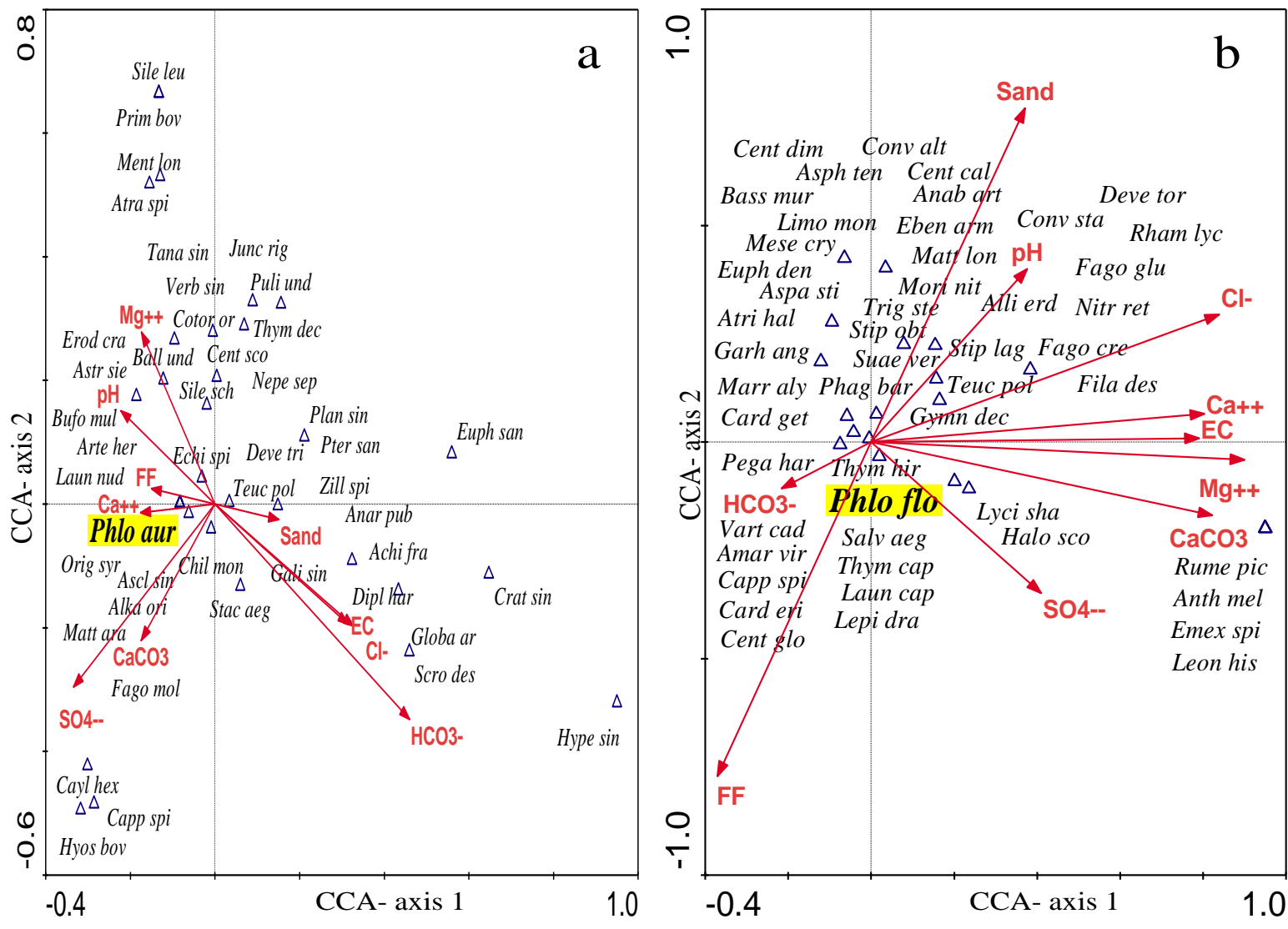

Fig. 5: Canonical correspondence analysis (CCA) ordination: (a) 20 plots of $P$. aurea and (b) 26 plots of $P$. floccosa. Soil variables are represented by arrows. The species are abbreviated to the first four letters of the genus and the first three letters of species names.

The eigenvalues of the first two axes of the canonical correspondence analysis are listed in Table (3). The percentage of speciesenvironment represented $24.7 \%$ at first axis in $P$. aurea, while it was $27.9 \%$ in $P$. floccosa at

Table (3): Eigenvalues, species-environment, and correlation ( $\mathrm{r} \mathrm{S} / \mathrm{E}$ ) percentage of species variance accounted for by first two axes of canonical correspondence analysis (CCA) ordination.

\begin{tabular}{|l|l|l|l|l|}
\hline \multirow{2}{*}{ Axis } & \multicolumn{2}{|c|}{ Phlomis aurea } & \multicolumn{2}{l|}{ Phlomis floccosa } \\
\cline { 2 - 5 } & Axis I & $\begin{array}{l}\text { Axis } \\
\text { II }\end{array}$ & Axis I & Axis II \\
\hline Eigenvalue & 0.269 & 0.209 & 0.353 & 0.226 \\
\hline $\begin{array}{l}\text { \% of species- } \\
\text { environment }\end{array}$ & 24.7 & 43.9 & 27.9 & 45.8 \\
\hline r (S/E) & 0.952 & 0.870 & 0.961 & 0.884 \\
\hline
\end{tabular}

\section{Discussion}

The flora of Egypt comprises about 2165 plant species, distributed in different habitats. Substantial part of this diversity is confined to the wettest regions - Mediterranean, Sinai Peninsula, and Gebel Elba, in addition to many introduced species that have been successfully the same axis. The eigenvalues are a much better measure of the quality of the ordination and of the strength of the species-environment relationship than the so-called speciesenvironment correlation (ter Braak, 1986).

acclimatized to the Egyptian conditions (Bolous, 2005). The rich flora of the Sinai Peninsula and the Mareotis coast includes a variety of medicinal plants, some of which are under-estimated. Medicinal plants have pivotal role in the traditional and orthodox medicine (Jadon and Dixit, 2014).

Edaphic factors have a significant influence on the distribution of plant communities within a landscape. A strong relationship between geomorphology, soil development and dominant vegetation types has been documented in the arid Chihuahuan Desert (Buxbaum and Vanderbilt, 2007). Different plant life forms exhibit distinct responses to various soil conditions (Hamerlynck et al., 2002). The high amount of rainfall and moisture contents in the coastal belt in the western Mediterranean section and Sinai Peninsula are responsible for the diverse vegetation in that area more than that of the landward areas and 
oases. Vegetation is the end product of three main components, namely: climate, soil, and water. The relation between plant life and climate is an intimate relationship (Zahran, 1982). Holdbridge (1974) said that structure forms, and growth habits of plants could be grouped into well marked plant communities of wild vegetation and that their grouping would reflect the climate of a given location.

El-Keblawy et al., 2015 resulted that the combination of landforms and soil characteristics have an important mediating influence on the distribution and abundance of the dominant plants in the deserts of the Northern Emirates (NE). Similarly, vegetation types were distributed based on different physical and chemical properties of soils in the Southeastern Tengger Desert, China (Li et al., 2004).

Soil salinity and texture are among the most important factors controlling the distribution of the dominant desert perennials in the Arabian deserts (Boer,1996). Boer and Sargeant (1998). Different plant life forms exhibit distinct responses to various soil conditions (Hamerlynck et al., 2002).

The present study showed soil variables in the microhabitats where $P$. aurea and $P$. floccosa in Egypt. Soil characteristics (physical and chemical properties) differ according to geomorphological processes and physiographic factors in different areas.

The maximum conductivity of soil in various microhabitats supporting $P$. floccosa growth is relatively higher $(950 \mu \mathrm{S} / \mathrm{cm})$ than that of $P$. aurea $(110.4 \mu \mathrm{S} / \mathrm{cm})$.

Life form spectra provide information, which may help in assessing the response of vegetation to different environmental factors of diverse habitats (Ayyad and El-Ghareeb 1982). Moustafa (1990) reported that the organisation of community types or associations was the net result of the behavior of the species in response to the environmental conditions that prevail in each particular habitat in SKP. In agreement with Abd El-Ghani (1998), Moustafa \& Abd El-Wahab (2013), Salama et al. (2013), Khafagi et al. (2013), Omar (2014) and Youssef et al. (2014) and Shaltout et al. (2016), the soil-vegetation relationships revealed that Cations and anions (Calcium, magnesium, chloride and bicarbonate ,calcium carbonates and Sulfates) also, soil reactions ( $\mathrm{pH}$ and EC). Finally, clay, organic matter, and fine gravel were the most important soil factors along the first 2 axes of Canonical Correspondence Analysis (CCA), which indicated their effect on $P$. aurea and $P$. floccosa distribution in SKP and coastal western Mediterranean coast of Egypt

The vegetation of south Sinai was characterized by the dominance of four families: Compositae, Zygophyllacae, Leguminosae, and Labiatae which include many endemic species (Moustafa 1990 and Hatim et al., 2016).

Under biogeographical aspects, the SaharoArabian chorotype of plants forms the major floristic structure of the study area. Plants of this chorotype are good indicators for desert environmental conditions (Abd El-Ghani and Amer 2003). Most of Sinai belongs to the Saharo-Arabian phytogeographical region, but the high mountains of southern Sinai support Irano-Turanian steppe vegetation (Omar 2014). South Sinai is characterized by arid to extremely arid climate (Danin 1986). The aridity and sparseness of vegetation made the ecosystem fragile and sensitive to human impacts. Vegetation depletion or removal due to human impacts, including cutting and uprooting of ligneous species for firewood, overgrazing, intensive collection of medicinal plants, tourism, and urbanization, induces changes in soil productivity and aggravates soil erosion (Batanouny 1983).

Species were assigned their critical status as a result of the observed habitat's loss, ecological imbalance or commercial exploitation during the last decades (El-Hadidi \& Hosni 2000; Shaltout et al. 2015). In most cases, there are two factors influencing the degree of endemism in an area: isolation and stability. Thus, isolated mountains and islands are often rich in endemics (Kingston and Waldren 2005). The vegetation analysis of the species associated with their distribution at the different microhabitats with $P$. aurea and P. floccosa. A number of 25 associated species were recorded throughout the present study, with large importance value (IV) in the different microhabitats where Phlomis species are common. Wadi bed and the Gorge were relatively floristically rich. We recorded 13 species belonging to Phanerophytes and Chamaephytes in those two microhabitats. In agreement with Ayyad et al. (2000) and Moustafa and Abd El-Wahab (2013) that gorges had the highest value of species richness. Meanwhile, the Slope and Basin microhabitats were moderate floristically, with 11 plant 
species. Although Terraces microhabitat possessed the largest importance value for $P$. aurea, it has poor vegetation (5 species only).we disagree with Moustafa and Abd El-Wahab (2013) that terraces highest species richness. Present study reported that the Achillea fragrantissima, Globularia arabica, Teucrium polium, Tanacetum sinaicum, Origanum syriacum and Stachys aegyptiaca were dominat association with $P$. aurea in different micro habitat. Abd El-Wahab (2006) reported that $P$. aurea, Teucrium polium, Tanacetum santolinoides, Seriphidium herba-alba, Stachys aegyptiaca, Echinops spinosissimus, Mentha longifolia, and Nepeta septemcrenata were the dominant species.

Shaltout et al. (2016) discussed that species had low density, cover and frequency values, perhaps they had difficult seed germination as some seeds of species need pre-germination treatments or some others had low survival and high mortality of seedlings, as well as low seed production through their juvenile stage (e.g. Polygala sinaica). While, (Moustafa et al. 2015) decided that, the high seed germination of the endemic species Origanum syriacum was obtained when seeds were soaked in GA3 (10ppm) for $24 \mathrm{~h}$ before sowing at room temperature.

Phlomis floccosa is native to North Africa and distributed in the North West region of Egypt in various microhabitats along the coast. The microhabitats inhibited by the target plant are represented in Wadi bed, Slope, Cleavage and Plateau with IVs of 41.43, 43.15, 55.99 and 43.92 respectively. Thus, $P$. floccosa is widely distributed in Cleavage microhabitat than the other localities. May be the reasons of shadow, humidity and soil moisture content.

In present study the association with P. floccosa in different micro habitat were Asphodelus ramosus. Ferula marmarica, Amaranthus viridis, Euphorbia dendroides, and Artemisia herba-alba.

\section{References}

Abd El Kader F.H. and Ahmed A.M. (1981) Soil and Water Studies in Regional Environmental Management of Mediterranean Desert Ecosystems of Northern Egypt. Progress Report 2, Vol. 3.

Abd El-Ghani M.M. and Amer W.M. (2003). Soilvegeta-tion relationship in a coastal desert plain of southern Sinai, Egypt. J. Arid. Environ. 55: 607-628.

Abd El-Wahab R.H., (2006). Landforms, vegetation, and soil quality in South Sinai, Egypt. The Egyptian Society for Environmental Sciences 1(2): 127-138.

Aitzetmuller K.; Tsevegsuren N. and Vosmann K. (1997). A new allenic fatty acid in Phlomis (Lamiaceae) Seed oil. Eine neue Allen-Fettsaure in Samenol von Phlomis (Lamiaceae).FettLipid.99:3,74-78.

Albaladejo R.G.; Aguilar J.F.; Aparicio A. and Feliner G.N. (2005). Contrasting nuclearplastidial phylogenetic patterns in the recently diverged Iberian $P$. crinita and $P$. lychnitis lineages (Lamiaceae). Taxon 54, 987-998.

Allen S. E. (1989). Chemical Analysis of Ecological Materials. Blackwell Scientific Publications. Oxford, London Edinburgh. Pp. 368.

Allen S.E.; Grimshaw H.M.; Parkinson J.A. and Quarmby C. and Roberts J.D. (1974). Chemical analysis of ecological materials. Blackwell Scientific, Oxford, $565 \mathrm{p}$.

Alluri N. and Majumdar M. (2014). Pytochemical analysis and in vitro antimicrobial activity of Calotropis Igantea, Lawsonia Inermis and Trigonella Foecum- Graecum. Int J.Pharm Pharm Sci, 6 (4)524-527.

Alqamy H. M. (2002). Developing and Assessing a Population Monitoring Program for Dorcas Gazelle (Gazella dorcas) Using Distance Sampling in Southern Sinai, Egypt. M.Sc. thesis, School of Biology, Division of Environmental \& Evolutionary Biology, University of St. Andrews, Scotland, 118 pp.

Ayyad M.A. and El-Ghareeb R. (1982). Salt marsh vegeta-tion of the Western Mediterranean desert of Egypt. Vegetatio 49(1): 3-19.

Ayyad M.A., Fakhry A.M. and Moustafa A.A. (2000). Plant biodiversity in the Saint Catherine area of the Sinai Peninsula, Egypt. Biodivers. Conserv. 9(2): 265-281.

Ayyad, M. A. (1973). Vegetation and environment of the Western Mediterranean coastal land of Egypt. I: Sand dune habitat. J. Ecol., 61:509523.

Bailey, C. and Danin, A. (1981). Bedouin plant utilization in the Sinai and the Negev. Economic Botany, 35: 145-162.

Batanouny K.H. (1983). Human impact on Desert Vege - tation. In: Holzner W., Werger M.J.A. \& Ikusima I. (eds.), Man's impact on Vegetation, Dr. W. Junk Publishers, The Hague: 139-149.

Boer B. (1998). Ecosystems, anthropogenic impacts, and habitat management techniques in $\mathrm{Abu}$ Dhabi. $\mathrm{PhD}$ dissertation, University of Paderborn, Germany. 
Böer B. and Sargeant D. (1998). Desert perennials as plantand soil indicators in Eastern Arabia. Plant Soil199:261-266.

Boulos L. (2002). Flora of Egypt. Vol. 3: Verbenaceae Compositae. Al-Hadara Publishing, Cairo, 373 pp.

Boulos L. (2005). Flora of Egypt. Vol. 4: Monocotyledons (Alismataceae-Orchidaceae). Al-Hadara Publishing, Cairo. 617 p.

Boulos L. (2009). Flora of Egypt checklist. Al-Hadra Publishing, Cairo, 410 p.

Buxbaum C.A.Z. and Vanderbilt K. (2007). Soil heterogeneity and the distribution of desert and steppe plant species across a desert-grassland ecotone. Journal of Arid Environments 69(4):617-632.

Danin A. (1986). Flora and vegetation of Sinai. Pro - ceedings of the Royal Society of Edinburgh, 89B: 159-168.

Danin A. 1983. Desert vegetation of Israel and Sinai coastal area. Willdenowia 11: 291-300.

El-Hadidi M. N. and Hosni H. A. (2000). Conservation and threats. In: El-Hadidi M.N. (ed.), Flora Aegyptiaca. Vol. I, part 1. Palm Press, Cairo: 151.

El-Keblawy A.; Abdel-Fattah M. and Khedr A. (2015). Relationships between landforms, soil characteristics and dominant xerophytes in the hyper-arid northern United Arab Emirates. Journal of Arid Environments 117: 28-36.

Fakhry, A. M. (1994). Species richness and diversity in the vegetation of the Western Mediterranean coastal desert of Egypt. Ph.D Thesis, Alex. Univ., Alexandria, Egypt. 128pp.

Gad A.; Abdel-Rahman M.A. and Shalabi A.A. (1999). Final report on: Cameleo Changes in Arid Mediterranean Ecosystems on the Long Term through Earth Observation. Institute of Graduate Studies and Research (IGSR) and National Agency for Remote Sensing and Space Sciences (NARSS), Cairo.

Ghalem B., Mohamed B. (2008). Contribution to the Antiseptic Effect Study of Two Eucalyptus Species. Advances in Natural and Applied Sciences, 2(3): 170-177.

Hamerlynck E.; T. Huxman T. Charlet, and Smith S. (2002). Effects of elevated CO2 (FACE) on the functional ecology of the drought-deciduous Mojave Desert shrub, Lycium andersonii. Environmental and Experimental Botany 48:93106.

Hatim M. Z.; Shaltout K. H.; Schamine J. H.; ElKady H. F.; Janssen J. and El-Sheikh M. A. (2016). VegEgypt ecoinformatics: contribution to Sinai flora and vege-tation. Rend. Fis. Acc. Lincei 27 :383-399.
Holdbridge, L. (1974). Determination of world plant formation from simple climate data. Sci., 105:357-368.

Huber-Morath A. (1982). Phlomis L. In: DAVIS, P.H. ed. Flora of Turkey and East Aegean Island. Edinburgh; Edinburgh University Press, vol. 7, p. 102-126.

IUCN. (1994). Centres for plant diversity: A guide and strategy for their conservation. Cambridge: International Union for the Conservation of Nature Publications Unit.

Jackson M.L. (1967). Soil Chemical Analysis. Hall of India. Prentice Hall, Inc. N.J. pp 248.

Jadon R. and Dixit S. (2014). Phytochemical extraction and antimicrobial activity of some medicinal plants on different microbial strains. Journal of Medicinal Plants Studies. (2) 3: 58-63.

Katagiri M.; Ohtani, K.; Kasai R.; Yamasaki K.; Yang C.R. and Tanaka O. (1994). Diterpenoid glycosyl esters from Phlomis younghusbandii and P.medicinalis roots. Phytochemistry, $35: 2,439-442$.

Khafagi O.; Hatabe E. and Mohamed A. (2013). Effect of spatial variation on plant community structure in South Sinai, Egypt. Universal Journal of Envi-ronmental Research and Technology 3(2): 242-254.

Khalmatov Kh. Kh.; Kharlamov, I. A.; Alimov, Kh. I. and Ikramov M. T. (1983). Components of Phlomis ostrowskiana. Khimiya Prirodnykh Soedinenii, 6,795-796.

Khedr A., 2007. Assessment, classification, and analysis of microhabitats supporting globally significant plant species. Conserv. Sustain. Use Med. Plants Arid Semi-arid Eco-systems Proj. Saint Katherine Prot. Egypt, Final Rep. EEAA, GEF UNDP, Cairo, Egypt.

Khedr A-H.; Cadotte, M. W.; El-Keblawy, A. and Lovett-Doust J. (2002). Phylogenetic diversity and ecological features in the Egyptian flora. Biodiversity and Conservation 11:1809-1824.

Kingston N. and Waldren S. (2005). A conservation appraisal of the rare and endemic vascular plants of Pitcairn Island. Biodiversity and Conservation 14: 781-800.

Kyriakopoulou I.; Magiatis P.; Skaltsounis A.L.; Aligiannis N. and Harvala C. (2001). Samioside, a New Phenylethanoid Glycoside with FreeRadical Scavenging and Antimicrobial Activities from Phlomis samia. J. Nat. Prod. 64, 10951097.

Li X.W. and Hedge I.C. (1994). Phlomis In: Z.Y. Wu, P.H. Raven (Eds.), Flora of China, Vol. 17. Science Press, Beijing and Missouri Botanical Grand Press, St. Louis, p. 143.

Li Y.; Cui J.; Zhao X.; and Zhao H. (2004). Floristic composition of vegetation and 
the soil seed bank in different types of dunes of Kerqin steppe. Arid land Res. Manag., 18: 283- 293.

Moustafa A. A. and Kamel W. M. (1995). Ecological notes on the floristic composition and endemic species of saint Catherine Mountains, South Sinai, Egypt. Qatar Univ. Sci. J. 15 (2): 339-352.

Moustafa A. A. and Klopatek J. M. (1995). Vegetation and landforms of the Saint Katherine area, Southern Sinai, Egypt. Journal of Arid Environments 30: 385-395.

Moustafa A. A.; Zaghloul M. S. and Ahmed N. R. (2015). Autoecology of Origanum syriacum a threatened plant species growing in Saint Catherine Mountains, South Sinai, Egypt. J. of Global Biosciences 4(8): 3104-3120.

Moustafa A.A. and Abd El-Wahab R.H. (2013). Soil fertility in South Sinai, Egypt. Lap Lambert Academic Publishing, Sarrebruck, 165 p.

Moustafa A.A., (1990). Environmental gradients and species distribution on Sinai Mountains. Ph.D. Thesis, Fac. Sci., Suez Canal Univ., Ismailia, 115 p.

Mueller-Dombois D. and Ellenberg H. (1974). Aims and Methods of Vegetation Ecology. New York, Wiley.

Norusis M.J. (2006): SPPS 15.0 Guide to Data Analysis. Upper Saddle River, N. J: Prentice Hall.

Norusis M.J. (2007): SPPS 15.0 Advanced Statistical Procedures. Upper Saddle River, N. J: Prentice Hall.

Omar K.A. (2014). Ecological and climatic attribute analysis for Egyptian Hypericum sinaicum. Am. J. Life Sci. 2 (6), 369-381.

Omar K.A. (2014). Ecological and climatic attribute analysis for Egyptian Hypericum sinaicum. American Journal of Life Sciences 2(6): 369381.

Page A.L.; Miller R.H. and Iceeney D.R. (1982): Methods of Soil Analysis, part 2. American Society of Agronomy and Soil Science society of America, Madison, Wisconsin, U.S.A.

Perevolotsky A.; Perevolotsky A. and Noy-Meir I. (1989). Enviromental adaption and economic change in a pastoral mountain society: the case of the jabaliyah Bedouin of the Mt. Sinai region. Mountain Research and Development, 9 (2): 153-164.

Piper C.S. (1950): Soil and Plant Analysis. Inter publisher, Inc. New York, pp 386.

Rechinger K.H. (1982). Flora Iranica. Graz-Austria: Akademic Druck-u, Verlagsanstalt, 150: 292313.
Richards L. A. (1954). Diagnosis and improvement of saline and alkali soils. USDA. Agric. Handbook 60. Washington D. C.

Salama F.; Abd El-Ghani M.; El-Naggar S. and AlJar-roushi M. (2013). Vegetation dynamics and species distribution patterns in the inland desert wadis of South Sinai, Egypt. Ecologia mediterranea 39(2): 93-110.

Saracolgu I.; Inoue M.; Calis I. and Ogihara, Y. (1995). Studies on constituents with cytotoxic and cytostatic activity of two turkish medicinal plants Phlomis floccosa D.Don (Lamiaceae) Part I. The leaf, stem and root. Egyptian Journal of Pharmaceutical Bulletin .18:10,1396-1400.

Serag M.M.; Moustafa A.R.A. and Qiqa S.S., (2018). Impact of Climate Change on Surviving of Phlomis aurea as an Endemic Species Growing in Southern Sinai, Egypt. Catrina-The International Journal Of Environmental Sciences, 16(2) 33-39.

Shabana H. (2013). Variability Among Phlomis Aurea Decne Populations In Southern Sinai. Ph.D. Thesis, Botany Department, Tanta University, Tanta, Egypt, pp: 290.

Shaltout K.H.; Ahmed D.A. and Shabana H.A. (2016). Distribution of the associated species with Phlomis aurea Decne along an elevation gradient in Southern Sinai, Egypt. ecologia mediterranea, 42(1) 65-77.

Shaltout K.H.; Ahmed D.A. and Shabana, H.A. (2015). Distribution of the associated species with Phlomis aurea Decne along an elevation gradient in Southern Sinai, Egypt. Ecologia Mediterranea, 42(1), $65-77$.

Shaltout K.H.; Heneidy S.Z.; Al-Sodany Y.M.; Marie A.M.; Eid E.M.; Hatimm M.Z. and ElGharaib A.E. (2004) Floristic Survey of the Mountainous Southern Sinai: Saint Katherine Protectorate, Conservation and Sustainable Use of Medicinal Individuals in Arid and Semi-arid Eco-systems Project, Egypt, Final Report (GEF \& UNDP).

Shmida A. (1984). Endemism in the flora of Israel. Botanische Jahrbucher fur Systematik Pflanzengeschichte und Pflanzengeographie, 104: 537-567.

Shukla K. S. and Chandel P. S. (1989). Plant Ecology and Soil Science. S. Chand and Co. New Delhi, India.

Täckholm V. (1974). Students’ Flora of Egypt. Cairo University. Cooperative Printing Company, Beirut, Lebanon.

Tanak O. (1985). Application of 13C-nuclear magnetic resonance spectrometry to structural .

Ter-Braak C.J.F. and Smilauer (1998). CANOCO Reference Manual and User's Guide to Canoco for Windows: Software for Canonical 
Community Ordination (Ver. 4). Microcomputer Power, Ithaca.

UNESCO (1996). Culture and health, orientation texts-world decade for cultural development 1998-1997. Document CLT/DEC/PRO-1996, Paris, France, p.: 129.

Varalakshmi K., Sangeetha C., Samee U., Irum G., Lakshmi H., Prachi S. (2011). In Vitro Safety Assessment of the Effect of Five Medicinal Plants on Human Peripheral Lymphocytes. Trop J. Pharm. Res., 10 (1): 33-40.

Wilde A.; Corey R.B.; Iyer and Voight, O.K. (1978) and plant analysis for tree culture. Oxford Publishing Company. New Delhi.
Youssef A.M.; Morsy A.A.; Mosallam H.A. and Hashim A.M., (2014). Vegetation and soil relationships in some wadis from the NorthCentral part of Sinai Peninsula, Egypt. Minia Science Bulletin, 25 (1): 1-28.

Zahran M. A. (1982). Vegetation types of Saudi Arabia. Pup. King Abdul Aziz Univ., Jeddah, Saudi Arabia, 61pp.

Zohary M., 1973. Geobotanical Foundations of the Middle East, Vols. 1 and 2. Gustav FischerVerlag, Stuttgart, pp: 739.

\section{عنوان البحث : التمايز المتخصص لنوعين من جنس الفلومس المتجانسة في مصر}

عبدالحميد خضر 1 ، طه القاطونى' ، خليل سعدالله” ، فاطمه أحمد” ، محمد قشلانه"

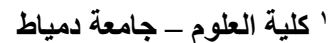

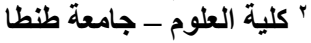

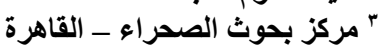

أظهرت الار اسة مدى كبير من التمايز والاختلاف في التوزيع البيئي والجغر افي لنوعي الزهيرة والعزئ العورور التابعين لجنس فلومس

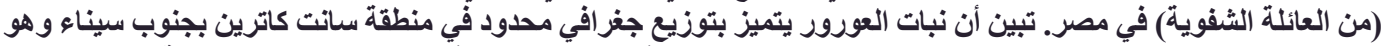

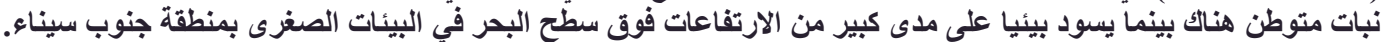

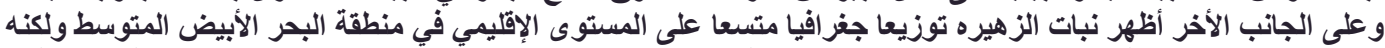

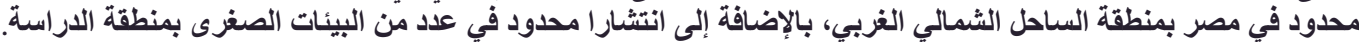

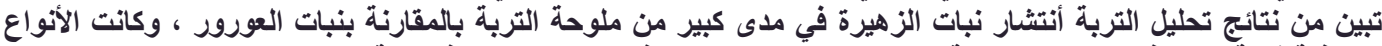

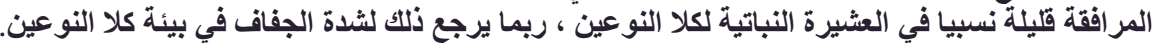

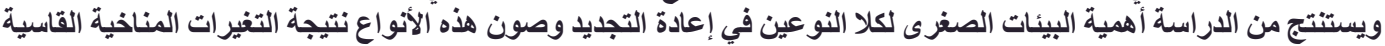

في مواقع انتشار ها. 